\title{
Pengaruh Pengungkapan CSR, Karakter Eksekutif, Profitabilitas, Dan Investasi Aktiva Tetap Terhadap Penghindaran Pajak
}

\author{
Ni K.Lely Aryani Merkusiwati ${ }^{1}$ \\ Fakultas Ekonomi dan Bisnis \\ Universitas Udayana, Indonesia. \\ Email: lelyaryanimer@unud.ac.id
}

\author{
I Gst Ayu Eka Damayanthi² \\ Fakultas Ekonomi dan Bisnis \\ Universitas Udayana, Indonesia.
}

\begin{abstract}
ABSTRAK
Penghindaran pajak (tax avoidance) merupakan salah satu cara untuk mengurangi jumlah pajak secara legal yang tidak melanggar peraturan perpajakan, berbeda dengan penggelapan pajak (tax evasion) yang menggunakan cara-cara yang melanggar hukum untuk mengurangi atau menghilangkan beban pajak sedangkan penghindaran pajak (tax avoidance) memanfaatkan celah (loopholes) yang terdapat dalam peraturan perpajakan untuk menghindari pembayaran pajak yang jumlahnya lebih besar. Penelitian ini dilakukan untuk mengetahui pengaruh Corporate Social Responsibility (CSR), karakter eksekutif, profitabilitas dan investasi aktiva tetap pada penghindaran pajak. Penelitian ini dilakukan pada perusahaan manufaktur yang terdaftar di Bursa Efek Indonesia tahun 2015-2017. Pengambilan sampel menggunakan teknik purposive sampling. Teknik analisis data yang digunakan pada penelitian ini adalah regresi linier berganda. Hasil uji regresi menunjukan CSR dan karakter eksekutif berpengaruh negatif terhadap penghindaran pajak. sedangkan profitabilitas dan investasi aktiva tetap tidak berpengaruh terhadap penghindaran pajak.
\end{abstract}

Kata Kunci : CSR; Karakter Eksekutif, Profitabilitas; Capital Intensity; Penghindaran Pajak.

Effects of CSR Disclosure, Executive Character, Profitability, and Fixed Asset Investment Against Tax Avoidance

\begin{abstract}
Tax avoidance is one way to reduce the amount of tax legally that does not violate tax regulations, in contrast to tax evasion, which uses unlawful methods to reduce or eliminate the tax burden while tax avoidance (tax avoidance) ) utilizing loopholes in tax regulations to avoid paying larger amounts of tax. This study was conducted to determine the effect of Corporate Social Responsibility (CSR), executive character, profitability and investment in fixed assets in tax avoidance. This research was conducted at manufacturing companies listed on the Indonesia Stock Exchange in 2015-2017. Sampling using a purposive sampling technique. The data analysis technique used in this study is multiple linear regression. Regression test results show that CSR and executive character negatively affect tax avoidance. while the profitability and investment of fixed assets have no effect on tax avoidance.
\end{abstract}

Keywords: CSR; Executive Character; Profitabilitas; Capital Intensity; Tax Avoidance.

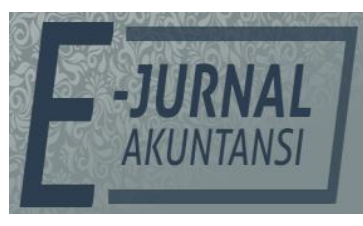

E-JA

e-Jurnal Akuntansi e-ISSN 2302-8556

Vol. 29 No. 2

Denpasar, November

2019

Hal. 833-853

Artikel masuk:

11 Oktober 2019

Tanggal diterima: 24 November 2019 


\section{PENDAHULUAN}

Penerimaan pajak di Indonesia sudah direncanakan sedemikian rupa supaya mencapai target yang diinginkan sesuai dengan Anggaran Pendapatan dan Belanja Negara (APBN). Data target dan realisasi penerimaan pajak tahun 20132016 disajikan dalam Tabel 1.

Tabel 1. Target dan Realisasi Penerimaan Pajak Tahun 2013 - 2016 (Dalam Triliun Rupiah)

\begin{tabular}{cccc}
\hline Tahun & Target Pemerintah & Realisasi & $\begin{array}{c}\text { Persentasi } \\
\text { pencapaian }(\%)\end{array}$ \\
\hline 2013 & 1.148 .400 & 1.077 .000 & 93,7 \\
2014 & 1.246 .100 & 1.146 .900 & 92,0 \\
2015 & 1.489 .300 & 1.240 .100 & 83,3 \\
2016 & 1.539 .200 & 1.094 .200 & 71,1 \\
\hline
\end{tabular}

Sumber : www.kemenkeu.go.id, 2017

Tabel 1. menunjukkan bahwa target penerimaan pajak dari tahun 2013 hingga 2016 terus meningkat, namun realisasi dengan target penerimaan tidak sesuai dengan yang diharapkan. Pemerintah belum mampu merealisasikan penerimaan pajak secara maksimal sesuai targetnya. Pertanyaan yang muncul apakah dari sisi wajib pajak terdapat beberapa tindakan yang dilakukan untuk meminimalkan pajaknya, ataukah memang pemungutan yang dilakukan belum mampu berjalan secara maksimal.

Upaya pemerintah dalam meningkatkan jumlah pajak berbanding terbalik dengan usaha perusahaan untuk menghindari pajak atau yang disebut tax avoidance. Penghindaran pajak bersifat unik karena dari sisi perusahaan sah untuk dilakukan tetapi tidak selalu diinginkan dari sisi pemerintah ( Maharani \& Suardana, 2014). Penghindaran pajak sebenarnya cukup banyak terjadi di Indonesia, misalnya kasus penggelapan pajak terbesar yang dilakukan oleh PT Asian Agri Tbk yang terbukti oleh Direktorat Jenderal Pajak (DJP) merugikan negara triliunan rupiah sehingga dikenakan sangsi berupa denda yang sangat besar (Dharmasaputra, 2013). Kasus penghindaran pajak di Indonesia juga dilakukan oleh PT Bumi Resources Tbk yang merupakan salah satu perusahaan keluarga di Indonesia. Bahkan, diduga penghindaran pajak PT Bumi Resources dan anak usahanya yaitu PT Kaltim Prima Coal (KPC) dan PT Arutmin Indonesia mencapai 2,1 triliun, atas kasus tersebut DJP telah menetapkan direktur keuangan PT Bumi Resources dan direktur PT Kaltim Prima Coal sebagai tersangka pidana penggelapan pajak (Tempo, 22 Maret 2010). Direktorat Jenderal Pajak Kementerian Keuangan (DJP Kemenkeu) juga menyatakan sebanyak 2.000 perusahaan multinasional yang beroperasi di Indonesia tidak membayar Pajak Penghasilan (PPh) Badan Pasal 25 dan Pasal 29 karena alasan merugi tetapi perusahaannya masih tetap eksis. Sebanyak 2.000 PMA (Penanaman Modal Asing) tersebut terdiri dari perusahaan di sektor perdagangan, dan sebagainya. Praktik penghindaran pajak ini dilakukan dengan modus mengalihkan keuntungan atau laba kena pajak dari Indonesia ke negara lain ( liputan6.com, 2016).

Penghindaran pajak di dunia internasional juga banyak terjadi. Setelah Amazon, Google dan beberapa perusahaan raksasa di Eropa tersandung masalah penghindaran pajak, kini giliran IKEA sebuah perusahaan raksasa yang 
bermarkas di Swedia. Sebagaimana dilaporkan media independen, perusahaan yang bergerak dibidang industri peralatan rumah tangga ini dikabarkan melakukan upaya penghindaran pajak dengan nilai lebih dari \$ 1 milyar. Upaya penghindaran pajak dalam skala besar ini terjadi dalam kurun waktu 2009 hingga 2014 ( Forum Pajak, 2016).

Pajak dan CSR memiliki kemiripan dalam hal keduanya memberikan kontribusi sosial kepada masyarakat. Apakah kemiripan ini dipandang sama oleh perusahaan sehingga terdapat pengaruh positif tingkat aktivitas CSR terhadap pembayaran pajak, atau apakah karena kemiripan ini membuat perusahaan-perusahaan dengan aktivitas CSR tinggi justru mengurangi beban pajaknya melalui aktivitas penghindaran pajak karena menganggap CSR sebagai beban. Jika perusahaan semakin menyadari pentingnya CSR, maka perusahaan akan semakin menyadari betapa pentingnya kontribusi perusahaan dalam membayar pajak bagi masyarakat umum ( Yoehana, 2013). Penelitian tentang hubungan antara penghindaran pajak dengan CSR sudah diteliti terlebih dahulu oleh beberapa peneliti dengan hasil yang berbeda-beda (Lanis \& Richardson 2012), (Yoehana 2013), (Nugraha 2015), (Davis et al., 2013), (Wahyudi 2015).

Penghindaran pajak yang dilakukan oleh perusahaan bukan merupakan suatu kebetulan, keputusan untuk melakukan penghindaran pajak merupakan hasil kebijakan perusahaan. Secara langsung, individu yang terlibat dalam pembuatan keputusan pajak adalah direktur pajak dan juga konsultan pajak perusahaan. Namun, eksekutif (direktur utama atau presiden direktur) sebagai pimpinan perusahaan secara langsung ataupun tidak langsung juga memiliki pengaruh terhadap segala keputusan yang terjadi dalam perusahaan, termasuk keputusan penghindaran pajak perusahaan. Pernyataan bahwa eksekutif memegang peranan penting dalam menentukan skema penghindaran pajak perusahaan diperkuat oleh penelitian yang dilakukan oleh (Budiman \& Sutiyono, 2012) yang meneliti pengaruh karakter eksekutif terhadap penghindaran pajak (tax avoidance), hasil dari penelitian tersebut menyatakan eksekutif yang memiliki karakter risk taker memiliki pengaruh yang positif terhadap penghindaran pajak (tax avoidance). Penelitian tersebut juga sejalan dengan penelitian yang dilakukan oleh (Dyreng et al. 2010) serta (Dewi dan Jati 2014).

Penghindaran pajak yang lain dilakukan dengan memfokuskan pada tingkat profitabilitas perusahaan. Profitabilitas merupakan kemampuan perusahaan dalam memeroleh laba. Menurut Surbakti (2012) perusahaan dengan profitabilitas yang tinggi akan cenderung melakukan penghindaran pajak. Perusahaan yang ingin melakukan penghindaran pajak harus semakin efisien sehingga tidak perlu membayar pajak dalam jumlah besar. Rendahnya beban pajak dikarenakan perusahaan dengan pendapatan yang tinggi berhasil memanfaatkan keuntungan dari adanya insentif pajak dan pengurang pajak yang lain (Darmadi, 2013). Penelitian yang dilakukan Nugroho (2011), Fatharani (2012), dan Darmawan (2014) menemukan ROA berpengaruh positif pada tax avoidance.

Karakteristik perusahaan merupakan salah satu faktor yang dapat memengaruhi perusahaan melakukan penghindaran pajak. Karakteristik perusahaan pada penelitian ini adalah investasi perusahaan dalam aktiva tetap 
yang dapat dilihat pada rasio intensitas modal (Muzakki, 2015). Menurut Rodriguez dan Arias (2012) aset tetap yang dimiliki perusahaan memungkinkan perusahaan memotong pajak akibat dari penyusutan aset tetap perusahaan setiap tahunnya. Hampir seluruh aset tetap akan mengalami penyusutan yang akan menjadi biaya penyusutan dalam laporan keuangan perusahaan. Sementara biaya penyusutan ini adalah biaya yang dapat dikurangkan dari penghasilan dalam perhitungan pajak perusahaan. Artinya semakin besar biaya penyusutan akan semakin kecil tingkat pajak yang harus dibayarkan perusahaan. Hal tersebut berdampak pada perusahaan dengan tingkat rasio intensitas modal yang besar menunjukan tingkat pajak efektif yang rendah. Tingkat pajak efektif yang rendah mengindikasikan perusahaan melakukan praktik penghindaran pajak.Penelitian yang menghubungkan antara investasi aktiva tetap telah dilakukan oleh (Lanis dan Richardson (2007), Delgado et al. (2014), Darmadi dan Zulaikha (2013), Putra dan Merkusiwati (2016).

Penelitian ini merupakan modifikasi dari penelitian yang dilakukan oleh (Wahyudi (2015) Wiguna (2016). Penelitian ini kembali meneliti tentang pengaruh corporate social responsibility pada penghindaran pajak dengan menambahkan variabel karakter eksekutif, profitabilitas dan capital intensity sebagai variabel independen.

Teori yang banyak disebutkan dalam akuntansi sosial dan lingkungan salah satunya adalah teori legitimasi (Tilling, 2004). Ghozali dan Chariri (2007) menyatakan bahwa legitimasi perusahaan atau organisasi dapat dilihat sebagai sesuatu yang diinginkan atau dicari perusahaan dari masyarakat dan sesuatu yang diberikan oleh masyarakat kepada perusahaan. Upaya perusahaan untuk mendapatkan legitimasi dari masyarakat adalah dengan melakukan suatu aktivitas tanggung jawab sosial atau yang biasa disebut dengan corporate social responsibility (CSR). Teori agensi menyatakan tentang adanya kontrak antara pihak pemberi wewenang (principal) kepada pihak yang mendapatkan wewenang (agent) dengan memberikan beberapa otoritas dalam pengambilan keputusan guna melakukan sesuatu yang berhubungan dengan kepentingan pihak principal (Jensen \& Meckling, 1976). Manajer melakukan berbagai cara untuk mencapai tujuan tersebut baik itu dengan tindakan yang baik maupun tindakan yang dapat merugikan berbagai pihak (Luayyi, 2010).

Perusahaan dalam mempertahankan kelangsungan hidupnya selalu berupaya untuk mendapatkan legitimasi atau pengakuan baik dari pemerintah, kreditor, investor, konsumen, maupun masyarakat sekitar ( Hidayati \& Murni, 2009). Konsep legitimasi menunjukkan adanya tanggung jawab perusahaan terhadap masyarakat. Teori legitimasi inilah yang kemudian mendasari hubungan pengungkapan CSR dengan penghindaran pajak.

Penghindaran pajak adalah salah satu hambatan yang terjadi dalam pemungutan pajak sehingga menyebabkan berkurangnya penerimaan kas Negara (Bactiar, 2015). Sedangkan CSR adalah tindakan sosial sebagai bentuk tanggung jawab sebuah perusahaan terhadap semua stakeholder-nya. Berdasarkan pandangan teori legitimasi, CSR merupakan salah satu bentuk cara mendapatkan legitimasi dari masyarakat, semakin tinggi tingkat pengungkapan CSR suatu perusahaan maka akan semakin tinggi pula reputasi perusahaan di mata masyarakat. 
Penelitian yang dilakukan oleh (A Watson (2011), (Lanis \& Richardson (2012), Yoehana (2013), dan Nugraha (2015), Wiguna (2016) juga menunjukkan adanya pengaruh negatif antara CSR tehadap penghindaran pajak. Semakin tinggi tingkat pengungkapan CSR yang dilakukan oleh perusahaan, diharapkan perusahaan tersebut tidak melakukan tindakan penghindaran pajak. Berdasarkan uraian di atas maka, hipotesis dalam penelitian adalah diturunkan sebagai berikut.

$\mathrm{H}_{1}$ : corporate social responsibility berpengaruh positif pada penghindaran pajak.

Eisenhardt (1989) menyatakan teori keagenan berkaitan dengan penyelesaian masalah yang dapat terjadi dalam hubungan keagenan, salah satunya masalah risiko yang muncul ketika principal dan agent memiliki pandangan yang berbeda terhadap risiko. Masalah yang terjadi bahwa principal dan agent dapat memilih tindakan yang berbeda karena preferensi risiko yang berbeda. Posisi, peran serta tujuan principal dan agent yang berbeda tersebut akan mengakibatkan konflik kepentingan.

Keputusan untuk melakukan penghindaran pajak bergantung pada individu eksekutif perusahaan. Penelitian Hanafi dan Harto (2014) menyatakan bahwa eksekutif yang berani mengambil risiko atau disebut sebagai risk taker akan lebih memiliki pengaruh terhadap penghindaran pajak dibandingkan dengan eksekutif yang tidak berani mengambil risiko (risk averse). Pernyataan tersebut juga didukung oleh penelitian yang dilakukan oleh Dewi dan Jati (2014), Butje dan Tjondro (2014) yang menjelaskan bahwa semakin eksekutif bersifat risk taker, semakin tinggi tingkat penghindaran pajak yang dilakukan perusahaan. Berdasarkan uraian di atas maka, hipotesis kedua dalam penelitian ini adalah:

$\mathrm{H}_{2}$ : Karakter eksekutif berpengaruh postif pada penghindaran pajak.

Para agen (manajer) memiliki keinginan untuk meningkatkan keuntungan atau profitabilitas perusahaan sebagai dampak dari adanya kompensasi dari pihak prinsipal (pemilik perusahaan). Menurut Lestari \& Sugiharto., (2007), ROA merupakan pengukur keuntungan bersih yang diperoleh dari penggunaan aktiva. Semakin tinggi nilai dari ROA, berarti semakin tinggi nilai dari laba bersih perusahaan dan semakin tinggi beban pajak perusahaan. Perusahaan yang memiliki laba bersih yang tinggi memiliki kesempatan untuk memposisikan diri dalam tax planning yang mengurangi jumlah beban kewajiban perpajakan (Chen et al., 2010).

Penelitian yang dilakukan oleh Kurniasih \& Sari (2013) menemukan bahwa ROA merupakan rasio dari profitabilitas berpengaruh secara signifikan terhadap penghindaran pajak. Tingginya profitabilitas perusahaan akan melakukan perencanaan pajak yang menghasilkan pajak optimal dengan meminimalkan beban pajaknya, sehingga perusahaan cenderung melakukan tax avoidance. Hal ini sejalan dengan penelitian yang dilakukan oleh Nugroho (2011), Fatharani (2012), dan Darmawan (2014) yang menemukan ROA berpengaruh positif pada tax avoidance. Berdasarkan uraian tersebut, maka dirumuskan hipotesis sebagai berikut:

$\mathrm{H}_{3}$ : Profitabilitas berpengaruh positif pada penghindaran pajak.

Teori agensi menjelaskan adanya perbedaan kepentingan antara pemilik saham dan manajemen. Kepentingan manajemen adalah untuk mendapatkan kompensasi yang diinginkan dengan cara meningkatkan kinerja perusahaan. 
Manajemen dapat memanfaatkan biaya penyusutan yang melekat pada aset tetap untuk menekan beban pajak perusahaan. Manajer akan menginvestasikan dana menganggur perusahaan ke dalam bentuk aset tetap, dengan tujuan memanfaatkan biaya depresiasinya sebagai pengurang beban pajak. Sehingga kinerja perusahaan akan meningkat karena adanya pengurangan beban pajak, dan kompensasi kinerja manajer yang diinginkan akan tercapai.

Liu dan Cao (2007) menyebutkan bahwa metode penyusutan aset didorong oleh hukum pajak, sehingga biaya penyusutan dapat dikurangkan pada laba sebelum pajak. Hal tersebut berarti semakin besar proporsi aktiva tetap dan biaya penyusutannya, perusahaan akan mempunyai nilai ETR yang rendah sehingga mengindikasikan tingkat penghindaran pajak perusahaan meningkat. Lebih lanjut, Richardson \& Lanis (2007), Putri \& Lautania (2016)) menjelaskan Capital intensity didefinisikan sebagai seberapa besar perusahaan menginvestasikan kekayaannya pada aset tetap. Hasil penelitian menyatakan bahwa semakin tinggi capital intensity ratio yang dimiliki perusahaan maka memiliki ETR yang rendah, yang mengindikasikan tingkat penghindaran pajak yang makin tinggi. Berdasarkan uraian diatas maka, hipotesis ketiga dalam penelitian ini adalah:

$\mathrm{H}_{4}$ : Investasi Aktiva tetap berpengaruh positif pada penghindaran pajak.

\section{METODE PENELITIAN}

Desain Penelitian merupakan hubungan logis dari landasan teoritis dan kajian empiris yang telah dijelaskan pada bagian sebelumnya. Konsep tersebut dapat disajikan dalam gambar 1 .

Penelitian ini dilakukan pada Bursa Efek Indonesia (BEI) yang memberikan informasi laporan keuangan dan laporan tahunan (annual report) perusahaan manufaktur dengan membeli dari situs resmi Bursa Efek Indonesia yaitu www.idx.co.id. Obyek dalam penelitian ini adalah penghindaran pajak yang diproksikan dengan nilai effective tax rates (ETR), corporate social responsibility, karakter eksekutif, profitabilitas dan investasi aktiva tetap perusahaan manufaktur yang terdaftar di Bursa Efek Indonesia periode 20142016. Alasan perusahaan manufaktur karena merupakan penyumbang pendapatan pajak negara terbesar selain industri pertambangan, keuangan dan perkebunan serta perusahaan manufaktur beberapa kali masuk sebagai wajib pajak yang difokuskan dalam daftar pemeriksaan Direktorat Jendral Pajak ( Mulyani \& Endang, 2014). Populasi dan sampel dalam penelitian ini adalah seluruh perusahaan manufaktur yang terdaftar di Bursa Efek Indonesia pada periode 2014-2016 yang telah dipilih menggunakan teknik purposive sampling.

Metode penentuan sampel yang digunakan dalam penelitian ini adalah metode non-probability sampling dengan teknik purposive sampling, yaitu pemilihan sampel dengan kriteria tertentu agar sampel yang terpilih lebih representatif.

Perusahaan manufaktur yang terdaftar di Bursa Efek Indonesia (BEI) periode 2014-2016 dan tidak didelisting selama periode penelitian. Perusahaan mempublikasikan laporan keuangan dan laporan tahunan (annual report) periode 2014-2016 secara berturut-turut.Perusahaan tidak mengalami kerugian selama tahun penelitian. Hal ini karena akan menyebabkan nilai ETR menjadi negatif 
sehingga akan menyulitkan penghitungan. Perusahaan mengungkapkan aktifitas CSR-nya dalam laporan tahunan periode 2014-2016 secara berturut-turut.

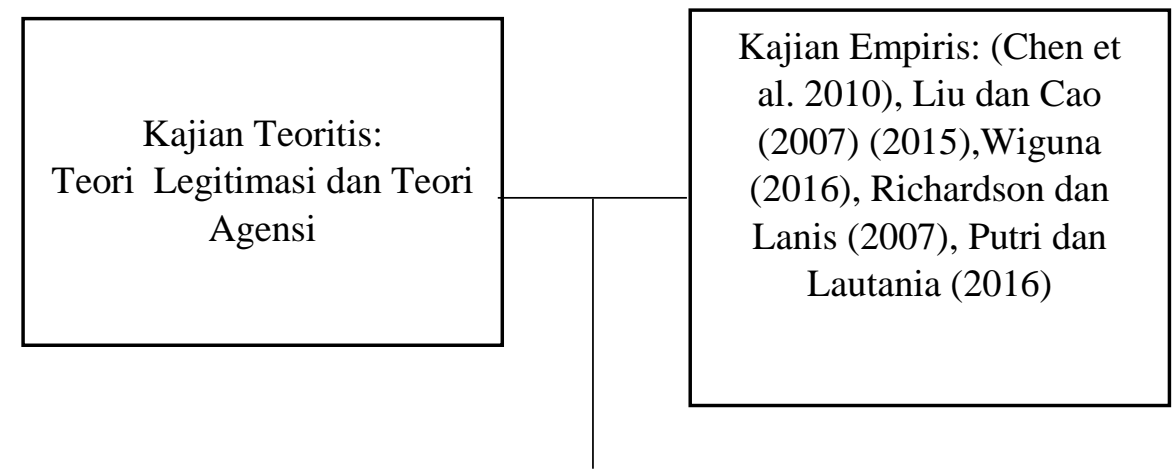

Hipotesis:

1. Pengungkapan Tangungjawab sosial berpengaruh positif pada Penghindaran Pajak

2. Karakter Eksekutif berpengaruh positif pada Penghindaran Pajak

3. Profitabilitas berpengaruh positif pada Penghindaran Pajak

4. Investasi aktiva tetap berpengaruh positif pada Penghindaran Pajak

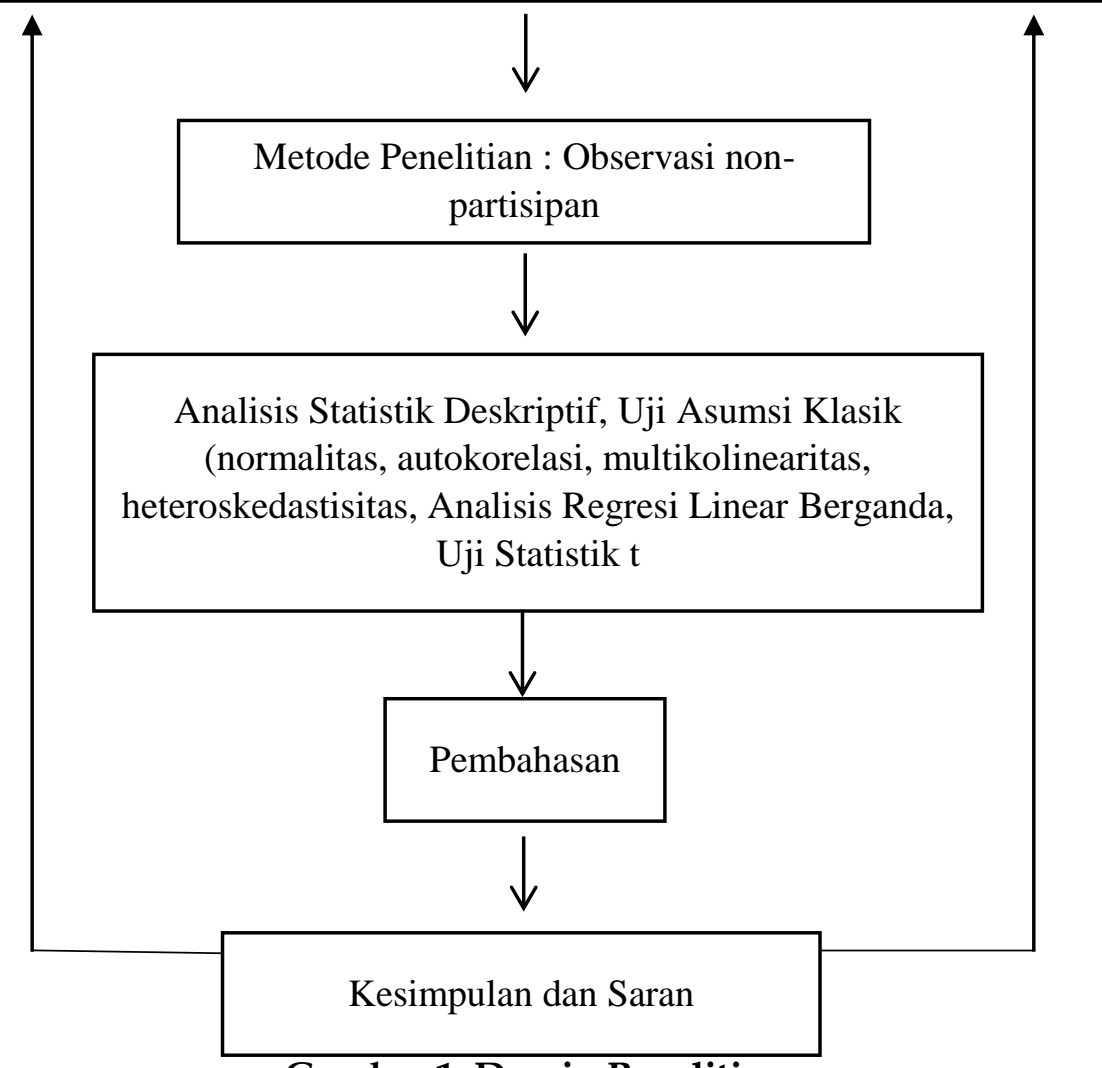

Sumber: Data Penelitian, 2018 
Model penelitian menjelaskan hubungan antara variable independen dan dependen dan menunjukan arah hipotesis. Model penelitian ini ditunjukan pada gambar 2.

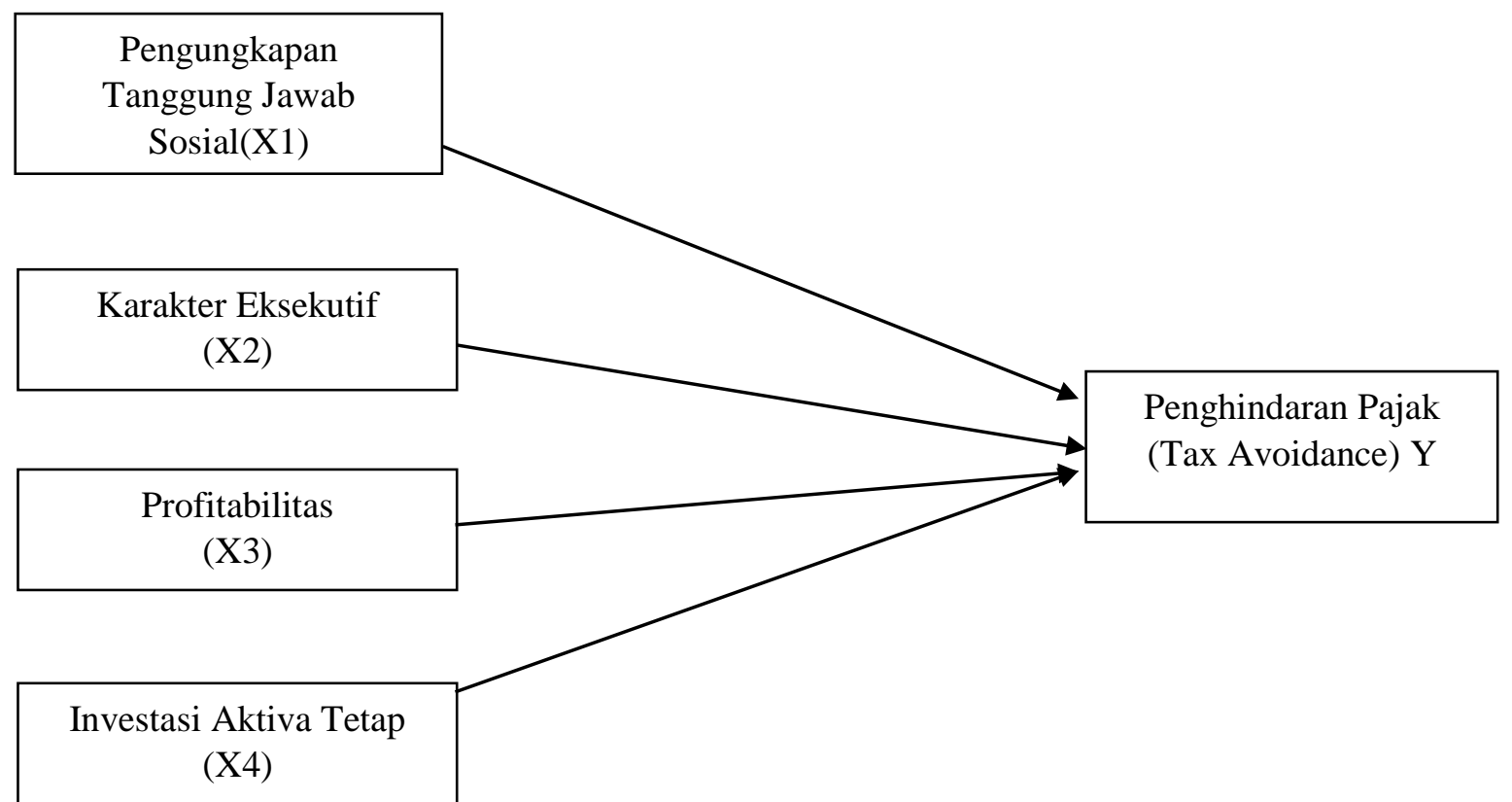

Sumber: Data Penelitian, 2018

Gambar 2. Model penelitian

Metode pengumpulan data yang digunakan dalam penelitian ini adalah metode observasi non-partisipan. Penelitian ini menggunakan dua jenis variabel, yaitu: Variabel terikat dalam penelitian ini adalah Penghindaran pajak $(Y)$ dan Variabel bebas dalam penelitian ini adalah corporate social responsibility $\left(X_{1}\right)$, karakter eksekutif $\left(X_{2}\right)$, profitabiltas $\left(X_{3}\right)$ dan investasi aktiva tetap $\left(X_{4}\right)$.

Variabel dependen dalam penelitian ini adalah penghindaran pajak. Penghindaran pajak dalam penelitian ini diproksikan menggunakan rasio Effective Tax Rates (ETR). ETR dalam penelitian ini hanya menggunakan model utama yang digunakan Lanis dan Richardson (2012), yaitu beban pajak penghasilan dibagi dengan pendapatan sebelum pajak perusahaan. Rasio ETR diukur dengan perhitungan sebagai berikut:

$E T R=\frac{\text { Beban Pajak kini }}{\text { Laba Sebelum Pajak }}$ Venelitian ini diproksikan menggunakan rasio pengungkapan CSR atau CSR disclosure. Penelitian ini menggunakan tabel checklist dengan indikator pengungkapan CSR yang mengacu pada indikator pengungkapan yang digunakan olehSembiring (2005) karena lebih sesuai dengan keadaan perusahaan di Indonesia, dimana pegungkapan CSR-nya masih bersifat umum dan belum rinci. Indikator ini terdiri atas tujuh kategori, yaitu lingkungan, energi, kesehatan dan keselamatan tenaga kerja, lain-lain tentang tenaga kerja, produk, keterlibatan masyarakat, dan umum. Jumlah item yang diharapkan diungkapkan perusahaan manufaktur adalah sebanyak 78 item. Pengukuran ini dilakukan dengan mencocokkan item pada checklist dengan item 
yang diungkapkan perusahaan. Apabila item y diungkapkan maka diberikan nilai 1, jika item y tidak diungkapkan maka diberikan nilai 0 pada checklist. Setelah mengidentifikasi item yang diungkapkan oleh perusahaan di dalam laporan tahunan, serta mencocokkannya pada checklist, hasil pengungkapan item yang diperoleh dari setiap perusahaan dihitung indeksnya dengan proksi CSRI. Adapun rumus untuk menghitung CSRI sebagai berikut:

$$
\text { CSRIi }=\frac{\sum x y i}{n i}
$$

Keterangan:

CSRIi = Indeks luas pengungkapan tanggung jawab sosial dan lingkungan perusahaan i.

$\Sigma$ Xyi $=$ nilai 1 : jika item y diungkapkan; $0:$ jika item y tidak diungkapkan.

ni $\quad=$ Jumlah item untuk perusahan $\mathrm{i}, \mathrm{ni} \leq 78$.

Variabel $\mathrm{X}_{2}$ adalah Karakter eksekutif dalam penelitian ini diproksikan menggunakan risiko perusahaan. Risiko perusahaan yang besar menunjukkan eksekutif memiliki preferensi risk taker dan begitu pula sebaliknya. Menurut Paligorova (2010) seperti yang dikutip dalam Budiman \& Sutiyono, (2012) risiko perusahaan dapat diukur dengan menggunakan rumus:

$$
\begin{aligned}
& R I S K=\sqrt{\sum_{t-1}^{T}\left(E-1 / T \sum_{t-1}^{T} E\right)^{2} /(T-1)} \\
& \text { Keterangan: } \\
& \mathrm{E}=\text { EBITDA (Earning Before Interest, Tax, Depreciation and } \\
& \text { Amortization)/Total aset } \\
& \mathrm{T}=\text { Total Sampel } \\
& \mathrm{t}=\text { Tahun }
\end{aligned}
$$

Variabel $\mathrm{X}_{3}$ Profitabilitas. Pengukuran profitabilitas yaitu menggunakan Return on Assest (ROA). ROA diperoleh dengan cara memberikan ukuran yang lebih baik atas profitabilitas perusahaan karena menunjukkan efektifitas manajemen dalam menggunakkan aktiva untuk memperoleh pendapatan. Berikut merupakan rumus ROA menurut ( Mardiyanto, 2009:62):

$$
R O A=\frac{\text { laba bersih setelah pajak }}{\text { total asset }}
$$

Variabel $\mathrm{X}_{4}$ Investasi Aktiva Tetap. Investasi aktiva tetap dalam penelitian ini diproksi menggunakan rasio intensitas aset tetap. Rasio intensitas aset tetap merupakan perbandingan total aset tetap terhadap total aset sebuah perusahaan (Rodriguez dan Arias, 2012). Rasio intensitas aset tetap diukur menggunakan rumus sebagai berikut:

$$
\text { Rasio Intensitas Aset Tetap }=\frac{\text { Total Aset Tetap }}{\text { Total Aset }}
$$

Teknik analisis data yang digunakan dalam menguji hipotesis penelitian ini adalah regresi linear berganda. Dalam menggunakan teknik analisis linier berganda, terlebih dahulu model yang akan diuji harus memenuhi syarat uji asumsi klasik. Analisis regresi linier berganda juga menghasilkan informasi yang berkaitan dengan uji kelayakan model (uji F), uji hipotesis (uji $t$ ) dan koefisien determinasi. Adapun model regresi dalam penelitian ini adalah sebagai berikut: $Y=\alpha+\beta_{1} X_{1}+\beta_{2} X_{2}+\beta_{3} X_{3+} \beta_{4} X_{4+} \varepsilon$

Keterangan:

Y : penghindaran pajak

$\mathrm{X}_{1} \quad$ : corporate social responsibility 
$\mathrm{X}_{2} \quad$ : karakter eksekutif

$\mathrm{X}_{3} \quad$ : profitabilitas

$\mathrm{X}_{4} \quad$ : investasi aktiva tetap

\section{HASIL DAN PEMBAHASAN}

Daerah atau wilayah penelitian yang digunakan dalam penelitian ini adalah perusahaan manufaktur yang terdaftar di Bursa Efek Indonesia tahun 2014-2016. Penentuan sampel penelitian menggunakan metode non-probability sampling dengan teknik purposive sampling, yaitu pemilihan sampel sesuai dengan kriteria tertentu. Berdasarkan kriteria pemilihan sampel yang digunakan, maka perusahaan yang memenuhi kriteria adalah sebanyak 44 perusahaan dengan proses penyeleksian Tabel 2.

Tabel 2. Hasil Seleksi Pemilihan Sampel

\begin{tabular}{clc}
\hline No. & \multicolumn{1}{c}{ Keterangan } & Jumlah \\
\hline 1 & $\begin{array}{l}\text { Perusahaan manufaktur yang terdaftar di Bursa Efek Indonesia } \\
\text { (BEI) periode 2014-2016 dan tidak didelisting selama periode } \\
\text { penelitian. }\end{array}$ & 145 \\
& $\begin{array}{l}\text { Perusahaan manufaktur yang tidak mempublikasikan laporan } \\
\text { keuangan dan laporan tahunan (annual report) periode 2014-2016 } \\
\text { secara berturut-turut. }\end{array}$ & $(37)$ \\
3 & $\begin{array}{l}\text { Perusahaan manufaktur yang mengalami kerugian selama tahun } \\
\text { 2014-2016. }\end{array}$ & Perusahaan manufaktur yang tidak mengungkapkan aktifitas CSR- \\
nya dalam laporan tahunan periode 2014-2016 secara berturut- \\
turut.
\end{tabular}

Sumber: Data Penelitian, 2018

Berdasarkan proses penentuan sampel maka, jumlah sampel perusahaan yaitu sejumlah 44 perusahaan dengan tahun observasi selama tiga tahun yaitu 2014-2016 jadi, jumlah keseluruhan sampel yaitu 132 sampel. Uji statistik deskriptif digunakan untuk memberikan gambaran suatu data yang dilihat dari rata-rata (mean), deviasi standar, nilai maksimum dan nilai minimum dari masing-masing variabel yang akan diteliti. Statistik deskriptif dari masingmasing variabel yang digunakan dalam penelitian ini dapat dilihat pada tabel 3 sebagai berikut.

Variabel independen CSR $\left(X_{1}\right)$ memiliki nilai rata-rata sebesar 0,106 dengan deviasi standar sebesar 0,073. Perusahaan yang memiliki nilai CSR terkecil adalah PT Darya Varia L.Tbk yaitu sebesar 0,01 pada tahun observasi 2014. Perusahaan dengan nilai CSR terbesar adalah PT Asahimas F Glass Tbk yaitu 0,38. Variabel independen preferensi risiko eksekutif $\left(\mathrm{X}_{2}\right)$ memiliki nilai rata-rata sebesar 0,017 dengan deviasi standar sebesar 0,012. Perusahaan yang memiliki nilai preferensi risiko eksekutif terkecil adalah PT Kedaung Setia 
Industrial Tbk yaitu sebesar 0,001 pada tahun observasi 2014. Perusahaan dengan nilai preferensi risiko eksekutif terbesar adalah PT Multi Bintang Indonesia Tbk yaitu 0,09.Variabel independen profitabilitas $\left(X_{3}\right)$ memiliki rata-rata sebesar 0,108 dan standar deviasi sebesar 0,124. Nilai minimum - 0,13 yaitu PT Sosial Bisnis Indonesia dan nilai maksimum 0,79 yaitu PT Ekadharma International Tbk. Variabel independen capital intensity $\left(\mathrm{X}_{4}\right)$ memiliki nilai rata-rata sebesar 0,314 dengan deviasi standar sebesar 0,144 . Perusahaan yang memiliki nilai capital intensity terkecil adalah PT Merck Tbk yaitu sebesar 0,09 pada tahun observasi 2017. Perusahaan dengan nilai capital intensity terbesar adalah PT Nippon Indosari Corporindo Tbk yaitu 0,78.Variabel dependen penghindaran pajak (Y) yang diproksikan dengan ETR memiliki nilai rata-rata sebesar 0,264 dengan deviasi standar 0,045. Perusahaan yang memiliki nilai ETR terkecil adalah PT Citra Turbindo Tbk yaitu 0,16 pada tahun observasi 2015. Perusahaan dengan nilai ETR terbesar adalah PT Sorini Agro Asia Corporindo Tbk yaitu 0,41. Tabel 3. Hasil Uji Statistik Deskriptif

\begin{tabular}{lrrrrr}
\hline & $N$ & Minimum & Maximum & Mean & $\begin{array}{c}\text { Std. } \\
\text { Deviation }\end{array}$ \\
\hline CRS & 132 & .01 & .38 & .106 & .073 \\
RISK & 132 & .00 & .09 & .017 & .012 \\
ROA & 132 & -.13 & .79 & .108 & .124 \\
CPIN & 132 & .09 & .78 & .314 & .144 \\
ETR & 132 & .16 & .41 & .264 & .045 \\
Valid N & 132 & & & & \\
(listwise) & & & & & \\
\hline Sumber: Data Penelitian, 2018 & & & & &
\end{tabular}

Penelitian ini juga mengunakan uji asumsi klasik yang meliputi uji normalitas, uji multikolinearitas, uji autokorelasi dan uji heteroskedastisitas. Uji asumsi klasik dilakukan dengan tujuan untuk memastikan hasil yang diperoleh memenuhi asumsi kuadrat terkecil di dalam analisis regresi. Hasil dari uji asumsi klasik yang diolah dengan bantuan software SPSS disajikan tabel 4.

Tabel 4. Hasil Uji Asumsi Klasik

\begin{tabular}{cccccc}
\hline Parameter & $\begin{array}{c}\text { Uji } \\
\text { yang diuji }\end{array}$ & \multicolumn{2}{c}{ Uji } & Uji & Uji \\
\cline { 2 - 5 } & $\begin{array}{c}\text { Asymp. Sig. } \\
(2 \text {-tailed })\end{array}$ & Tolerance & VIF & DW & Sig. \\
\hline $\begin{array}{c}\text { Unstandardiz } \\
\text { ed Residual }\end{array}$ & 0,200 & & & & \\
CSR & & 0,991 & 1,009 & & 0,453 \\
RISK & 0,820 & 1,220 & & 0,144 \\
ROA & & 0,836 & 1,196 & & 0,792 \\
CPIN & & 0,962 & 1,04 & & 0,725 \\
$\begin{array}{c}\text { Durbin- } \\
\text { Watson }\end{array}$ & & 0 & & 1,749 & \\
\hline
\end{tabular}

Sumber: Data Penelitian, 2018 
Pengujian normalitas dalam penelitian ini dilakukan dengan menggunakan uji statistik Kolmogorov-Smirnov. Jika nilai Asymp. Sig. (2-tailed) lebih besar dari tingkat signifikansi $a=0,05$ maka dapat disimpulkan data tersebut berdistribusi normal. Berdasarkan tabel 5.3 dapat dilihat nilai Asymp. Sig. (2-tailed) sebesar 0,200 lebih besar dari tingkat signifikansi a=0,05 maka dapat disimpulkan data yang dianalsis berdistribusi normal. Untuk menguji ada atau tidaknya korelasi di antara variabel independen dapat dilihat dari nilai tolerance dan nilai varian inflation factor (VIF). Jika nilai tolerance $>0,1$ dan nilai VIF $<10$ menunjukkan bahwa variabel independen yang digunakan tidak saling berkorelasi. Berdasarkan tabel 5.3 dapat dilihat bahwa nilai tolerance masingmasing variabel bebas lebih besar dari 0,1 dan nilai VIF kurang dari 10, sehingga dapat disimpulkan bahwa variabel bebas tidak saling berkorelasi secara signifikan. Hasil pengujian ini menunjukkan bahwa data yang dianalisis memenuhi asumsi multikolinear. Model regresi yang baik adalah model regresi yang tidak memiliki masalah autokorelasi. Berdasarkan nilai DW pada tabel 5.3 sebesar 1,749.Sesuai dengan tabel keputusan $\mathrm{dU}<\mathrm{d}<4$-dU $(1,7466<1,749<2,2534)$ maka dapat disimpulkan bahwa data terbebas dari autokorelasi. Pengujian ini dilakukan dengan uji Glejser. Dari hasil pengujian tersebut, apabila nilai signifikansinya $\geq 5 \%$, maka dapat disimpulkan bahwa dalam model tidak mengandung heteroskedastisitas. Berdasarkan pada tabel 5.3 dapat dilihat bahwa nilai Sig. dari masing-masing variabel bebas lebih dari 0,05 yang berarti tidak terdapat pengaruh antara variabel bebas terhadap absolute residual. Disimpulkan bahwa dalam model regresi tidak mengandung gejala heteroskedastisitas.

Hasil Uji Hipotesis Analisis linier berganda dilakukan untuk mengetahui pengaruh variabel-varibel bebas terhadap variabel terikat. Uji ini dilakukan untuk mengetahui besarnya pengaruh corporate social responsibility $\left(\mathrm{X}_{1}\right)$, preferensi risiko eksekutif $\left(X_{2}\right)$, profitabilitas $\left(X_{3}\right)$, dan capital intensity $\left(X_{3}\right)$ pada penghindaran pajak $(\mathrm{Y})$.

Tabel 5. Hasil Uji Regresi Linier Berganda

\begin{tabular}{lrr}
\hline Uji Statistik t & B & Sig. \\
\hline Konstanta & 0,291 & 0,000 \\
CSR & $-0,136$ & 0,009 \\
RISK & $-1,060$ & 0,004 \\
ROA & 0,007 & 0.833 \\
& & 0,530 \\
CPIN & 0,017 & \\
Uji Statistik F & & \\
$\quad$ Nilai F & 3,969 & \\
$\quad$ Sig. & 0,005 & \\
Uji Koefisien Determinasi & & \\
$\quad$ R-square & & \\
Adjusted R-Square & 0,111 & \\
\hline
\end{tabular}

Dependent Var: ETR

Sumber: Data Penelitian, 2018 
Berdasarkan tabel 5 diatas dapat dibuat persamaan regresi sebagai berikut.

$$
Y=0,291-0,136 X_{1}-1,060 X_{2}+0,007 X_{3}+0,017 X_{4}+\varepsilon
$$

Koefisien Determinasi bertujuan untuk melihat atau mengukur seberapa jauh kemampuan model dalam menerangkan variasi variabel dependen. Mengetahui kontribusi dari variabel independen terhadap variabel dependen dilihat dari nilai Adjusted R-Square. Pada tabel 5.4 memperlihatkan bahwa besarnya nilai Adjusted R-Square sebesar 0,083 memiliki arti bahwa 8,3 persen variabel penghindaran pajak yang diproksikan dengan ETR dipengaruhi oleh corporate social responsibility $\left(X_{1}\right)$, preferensi risiko eksekutif $\left(X_{2}\right)$, profitabilitas $\left(X_{3}\right)$ dan capital intensity $\left(X_{4}\right)$. Sisanya 91,70 persen dipengaruhi oleh faktor-faktor lain yang tidak dimasukkan dalam model penelitian.

Uji F bertujuan untuk mengetahui apakah model regresi yang digunakan dianggap layak uji atau tidak. Derajat kepercayaan yang digunakan adalah 0,05. Jika nilai signifikansi $\mathrm{F} \leq 0,05$ maka model regresi dikatakan layak dan dapat digunakan untuk memprediksi variabel dependen. Berdasarkan tabel 5.4 memperlihatkan nilai signifikansi $F$ sebesar 0,005 lebih kecil dari $a=0,05$ sehingga dapat disimpulkan bahwa model ini layak digunakan dalam penelitian dan dapat digunakan untuk memprediksi variabel dependen.

Uji $\mathrm{t}$ digunakan untuk melihat apakah hipotesis yang diajukan dapat diterima atau ditolak. Dasar pengambilan keputusan yaitu Jika nilai signifikansi $t$ $\leq$ 0,05 maka hipotesis diterima artinya variabel independen secara individual berpengaruh terhadap variabel dependen, begitu juga sebaliknya. Hasil uji statistik $\mathrm{t}$ terlihat pada tabel 5. Pengaruh corporate social responsibility $\left(\mathrm{X}_{1}\right)$ pada ETR (Y) menunjukkan nilai Sig. t 0,009 dengan nilai koefisien regresi sebesar 0,136. Nilai Sig. t 0,009 lebih kecil dari 0,05 menunjukkan bahwa CSR berpengaruh terhadap ETR. Koefisien regresi sebesar -0,136 menunjukkan arah yang negatif, berarti semakin tinggi nilai CSR maka semakin rendah nilai ETR. Dapat disimpulkan pengungkapan CSR berpengaruh pada penghindaran pajak, sehingga hipotesis $\mathrm{H}_{1}$ diterima. Pengaruh preferensi risiko eksekutif $\left(\mathrm{X}_{2}\right)$ pada ETR (Y) menunjukkan nilai Sig. t 0,004 dengan nilai koefisien regresi sebesar 1,060. Nilai Sig. t 0,004 lebih kecil dari 0,05 menunjukkan bahwa preferensi risiko eksekutif (RISK) berpengaruh terhadap ETR. Koefisien regresi sebesar -1,060 menunjukkan arah yang negatif, berarti semakin tinggi nilai preferensi risiko eksekutif (RISK) maka semakin rendah nilai ETR. Dapat disimpulkan bahwa semakin tinggi nilai preferensi risiko eksekutif berarti semakin tinggi tindakan penghindaran pajak. Hal ini sejalan dengan hipotesis $\mathrm{H}_{2}$ yang menyatakan bahwa preferensi risiko eksekutif berpengaruh pada penghindaran pajak sehingga hipotesis diterima.

Profitabilitas $\left(\mathrm{X}_{3}\right)$ pada ETR $(\mathrm{Y})$ menunjukkan nilai Sig. $\mathrm{t}$ 0,833 dengan nilai koefisien regresi sebesar 0,007. Nilai Sig. t 0,833 lebih besar dari 0,05 menunjukkan bahwa profitabilitas tidak berpengaruh terhadap ETR yang menjadi proksi penghindaran pajak. Namun, hipotesis $\mathrm{H}_{3}$ menyatakan profitabilitas berpengaruh pada penghindaran pajak sehingga hipotesis ditolak.Pengaruh capital intensity $\left(\mathrm{X}_{4}\right)$ pada ETR $(\mathrm{Y})$ menunjukkan nilai Sig. $\mathrm{t}$ 0,530 dengan nilai koefisien regresi sebesar 0,017. Nilai Sig. t 0,530 lebih besar 
dari 0,05 menunjukkan bahwa capital intensity tidak berpengaruh terhadap ETR yang menjadi proksi penghindaran pajak. Namun, hipotesis $\mathrm{H}_{4}$ menyatakan capital intensity berpengaruh positif pada penghindaran pajak sehingga hipotesis ditolak.

Pembahasan hasil uji statistik menunjukkan bahwa corporate social responsibility berpengaruh penghindaran pajak dengan nilai koefisien yang negatif. Artinya semakin tinggi nilai corporate social responsibility maka semakin rendah nilai ETR. Nilai ETR yang semakin rendah memberikan gambaran semakin tinggi tindakan penghindaran pajak. Disimpulkan bahwa semakin tinggi tingkat pengungkapan corporate social responsibility, maka semakin tinggi tindakan penghindaran pajak perusahaan. Hasil ini sesuai dengan hipotesis $\mathrm{H}_{1}$ yang menyatakan corporate social responsibility berpengaruh pada penghindaran pajak sehingga hipotesis $\mathrm{H}_{1}$ dapat diterima.

Hal ini memberikan gambaran walaupun perusahaan melaksanakan aktivitas CSR dan mengungkapkannya dalam laporan tahunan, perusahaan tetap melakukan tindakan penghindaran pajak. CSR yang seharusnya menjadi kewajiban bagi perusahaan masih beranggapan bahwa CSR sebagai beban dan bukan lagi sebagai bagian dari pengembangan masyarakat (Rusydi dan Veronica, 2014). Berdasarkan hal tersebut, perusahaan akan melakukan tindakan penghindaran pajak, yang mana hasil dari penghindaran pajak tersebut akan kembali dialokasikan dalam bentuk kegiatan CSR perusahaan. CSR dan pajak memiliki kemiripan dalam hal keduanya memberikan kontribusi sosial kepada masyarakat. Hal ini memberikan pandangan bahwa perusahaan-perusahaan dengan aktivitas CSR tinggi justru mengurangi beban pajaknya melalui aktivitas penghindaran pajak.

Hasil penelitian ini mendukung argumen Avi-Yonah (2008) yang memberikan temuan pengungkapan CSR tidak mengiringi tindakan perusahaan dalam perpajakannya. Artinya walaupun perusahaan telah mengungkapkan CSR dalam laporan tahunannya perusahaan tetap melakukan tindakan penghindaran pajak. Rusydi dan Veronica (2014) juga menjelaskan bahwa perusahaan yang selama ini menyatakan telah melaksanakan aktivitas CSR, ternyata banyak yang tersangkut masalah pidana perpajakan dalam hal ini penghindaran pajak seperti halnya kasus PT. Asian Agri yang memberikan beasiswa melalui Tanoto Foundation ternyata melakukan tindakan penghindaran pajak melalui transfer pricing. Davis et al. (2013) dalam penelitiannya juga menemukan bahwa pengukuran kualitas pelaporan akuntabilitas perusahaan dan indeks CSR berhubungan positif dengan aktifitas lobi untuk mengurangi pajak perusahaan.

Hasil uji Statistik menunjukkan bahwa preferensi risiko eksekutif berpengaruh negatif terhadap penghindaran pajak. Artinya semakin tinggi nilai risiko perusahaan (RISK) yang menjadi proksi dari preferensi risiko eksekutif maka semakin rendah nilai ETR. Nilai ETR yang semakin rendah mengindikasikan semakin tinggi tindakan penghindaran pajak. Disimpulkan bahwa semakin tinggi risiko perusahaan (RISK), maka semakin tinggi tindakan penghindaran pajak.

Berdasarkan hasil analisis tersebut, preferensi risiko eksekutif yang diindikasikan dengan tinggi rendahnya risiko perusahaan (RISK) dapat 
mencerminkan preferensi risiko eksekutif dalam mengambil keputusan, termasuk keputusan dalam melakukan tindakan penghindaran pajak. Semakin tingginya nilai risiko perusahaan (RISK) mencerminkan preferensi risiko eksekutif yang risk taker dan begitu pula sebaliknya, nilai risiko perusahaan yang rendah mencerminkan preferensi risiko eksekutif yang risk averse. Penghindaran pajak merupakan tindakan yang memiliki risiko tinggi, hanya eksekutif yang berani mengambil risiko yang akan melakukan hal tersebut. Melakukan tindakan penghindaran pajak berarti tidak ikut berpartisipasi dalam pembangunan nasional melalui pembayaran pajak. Oleh karena itu, eksekutif perusahaan yang cenderung memiliki preferensi risiko eksekutif risk taker akan lebih berani dalam menentukan suatu kebijakan penghindaran pajak perusahaan walaupun memiliki risiko yang tinggi. Hasil penelitian ini mendukung penelitian yang dilakukan oleh Dewi \& Jati (2014), Hanafi \& Harto (2014) dan Butje \& Tjondro (2014) yang menjelaskan bahwa semakin eksekutif bersifat risk taker, semakin tinggi tingkat penghindaran pajak yang dilakukan perusahaan.

Berdasarkan hasil uji statistik menunjukkan bahwa ROA tidak berpengaruh terhadap ETR sehingga hipotesis $\left(\mathrm{H}_{3}\right)$ yang menyatakan profitabilitas berpengaruh positif pada penghindaran pajak ditolak. Profitabilitas yang diukur dengan ROA tidak berpengaruh terhadap penghindaran pajak karena aset yang dimiliki oleh perusahaan sampel rata-rata berupa tanah dan bangunan dimana tanah tidak disusutkan sedangkan bangunan memiliki masa manfaat 20 tahun dengan tarif depresiasi sebesar 5 persen. Hal ini menyebabkan beban penyusutannya rendah dan pada akhirnya tidak secara signifikan mengurangi laba kena pajak perusahaan.

Hasil penelitian ini konsisten dengan penelitian yang dilakukan oleh Rego \& Wilson, (2012) serta Winoto (2015) yang mendapatkan hasil penelitian bahwa profitabilitas tidak berpengaruh pada penghindaran pajak. Berdasarkan hasil penelitian maka dapat disimpulkan bahwa profitabilitas yang diukur dengan ROA tidak memengaruhi tindakan penghindaran pajak yang dilakukan perusahaan.

Hasil uji statistik menunjukkan bahwa capital intensity tidak berpengaruh terhadap ETR yang menjadi proksi dari penghindaran pajak. Oleh karena itu, hipotesis $\mathrm{H}_{4}$ yang menyatakan capital intensity berpengaruh positif pada penghindaran pajak tidak dapat diterima.

Capital intensity didefinisikan sebagai seberapa besar perusahaan menginvestasikan kekayaannya pada aset tetap. Hampir semua aset tetap mengalami penyusutan dan biaya penyusutan dapat mengurangi jumlah pajak yang dibayar perusahaan. Hanum (2013) menjelaskan biaya penyusutan merupakan biaya yang dapat dikurangkan dari penghasilan dalam menghitung pajak. Artinya semakin besar jumlah aset tetap yang dimiliki perusahaan maka akan semakin besar pula biaya penyusutannya sehingga mengakibatkan jumlah penghasilan kena pajak dan ETR-nya akan semakin kecil. ETR yang semakin kecil memberikan gambaran tindakan penghindaran pajak perusahaan semakin besar.

Hasil penelitian ini tidak menemukan adanya pengaruh jumlah aset tetap yang besar terhadap tindakan penghindaran pajak yang dilakukan perusahaan. Tidak adanya pengaruh dari jumlah aset tetap yang dimiliki 
perusahaan diakibatkan oleh perusahaan dengan jumlah aset tetap yang besar memang menggunakan aset tetap tersebut untuk kepentingan perusahaan, yaitu menunjang kegiatan operasional perusahaan yang digunakan untuk penyediaan barang dan jasa. Menurut Fajar (2015) perusahaan bukan sengaja menyimpan proporsi aset tetap yang besar untuk menghindari pajak melainkan perusahaan memang menggunakan aset tetap tersebut untuk tujuan operasional perusahaan. Aset tetap tidak mampu memengaruhi kecenderungan perusahaan untuk melakukan tindakan penghindaran pajak. Hasil penelitian ini sejalan dengan hasil penelitian yang dilakukan oleh Nugraha (2015), Putra \& Merkusiwati (2015) bahwa proporsi aset tetap yang besar tidak akan memengaruhi tingkat penghindaran pajak yang dilakukan perusahaan.

\section{SIMPULAN}

Pengungkapan CSR berpengaruh pada penghindaran pajak. Semakin tinggi perusahaan mengungkapkan CSR, maka semakin tinggi tindakan penghindaran pajak perusahaan. Hal tersebut dikarenakan aktifitas CSR yang dilakukan masih dianggap sebagai beban dan bukan lagi sebagai bagian dari pengembangan masyarakat. CSR dan pajak memiliki kemiripan dalam hal sama-sama memberikan kontribusi sosial kepada masyarakat. Berdasarkan hal itu, perusahaan akan meminimalkan beban pajaknya dengan tindakan penghindaran pajak lalu memanfaatkan hasil dari tindakan penghindaran pajak untuk dialokasikan ke kegiatan CSR. Preferensi risiko eksekutif berpengaruh pada penghindaran pajak. Preferensi risiko eksekutif yang diproksikan dengan risiko perusahaan dapat mempengaruhi tindakan penghindaran pajak perusahaan. Semakin tinggi risiko perusahaan yang mencerminkan eksekutif bersifat risk taker maka semakin tinggi tingkat penghindaran pajak perusahaan. Profitabilitas tidak berpengaruh pada penghindaran pajak.Hal ini dikarenakan aset yang dimiliki oleh perusahaan sampel rata-rata berupa tanah dan bangunan dimana tanah tidak disusutkan sedangkan bangunan memiliki masa manfaat 20 tahun dengan tarif depresiasi sebesar 5 persen. Hal ini menyebabkan beban penyusutannya rendah dan pada akhirnya tidak secara signifikan mengurangi laba kena pajak perusahaan.

Capital intensity tidak berpengaruh terhadap penghindaran pajak. Capital intensity yang diproksikan dengan jumlah aset tetap tidak mempengaruhi tindakan penghindaran pajak perusahaan. Perusahaan yang memiliki aset tetap yang besar bukan digunakan perusahaan sebagai pengurang pajak karena biaya penyusutan yang melekat pada aset tetap, melainkan untuk menunjang kegiatan operasional perusahaan.

Berdasarkan kesimpulan yang telah disampaikan sebelumnya, maka saran yang dapat diberikan adalah sebagai berikut.

Berdasarkan uji koefisien determinasi yang bertujuan untuk melihat seberapa jauh model regresi dalam menerangkan variabel dependen yaitu penghindaran pajak. Dalam penelitian ini nilai Adjusted R-Square sebesar 0,083 atau 8,3 persen, artinya hanya 8,3 persen penghindaran pajak dipengaruhi oleh variabel-variabel yang digunakan dalam penelitian ini sedangkan 91,7 persen dipengaruhi oleh variabel lain yang tidak dimasukan dalam penelitian. Peneliti selanjutnya yang ingin meneliti tindakan penghindaran pajak perusahaan dapat menganalisis 
variabel-variabel lain yang mampu mempengaruhi tindakan penghindaran pajak seperti koneksi politik dan kompensasi manajemen. Pemerintah khususnya Direktorat Jendral Pajak agar dapat meningkatkan pengawasannya terhadap praktik penghindaran pajak, karena perusahaan yang selama ini menyatakan bahwa perusahaannya melaksanakan aktifitas CSR ternyata tetap melakukan penghindaran pajak. CSR merupakan suatu kontribusi sosial terhadap masyarakat begitu juga dengan pembayaran pajak. Seharusnya perusahaan yang telah melaksanakan aktifitas CSR tidak mengurangi jumlah beban pajaknya melalui tindakan penghindaran pajak, karena melakukan penghindaran pajak berarti tidak ikut berpartisipasi dalam pembangunan nasional melalui pemerintah dengan membayar pajak.

Penelitian ini mengidentifikasi item pengungkapan CSR pada laporan tahunan perusahaan yang berasal dari website BEI, sehingga peneliti mengasumsikan bahwa apabila item pengungkapan CSR tidak diungkapkan dalam laporan tahunan berarti perusahaan tidak melakukan aktivitas CSR. Oleh karena itu, peneliti selanjutnya dapat menggali informasi terkait pengungkapan CSR menggunakan metode lain seperti wawancara langsung atau melihat pada website perusahaan terkait implementasi CSR yang dilakukan perusahaan.

\section{REFERENSI}

Anthony, R., N. A. V. G. (2019). Managemen Control System Buku 2 Jakarta: Salemba Empat.

Asri, Ida Ayu Trisna Yudi dan Suardana, Ketut Alit. (2016). Pengaruh Proporsi Komisaris Independen, Komite Audit, Preferensi Risiko Eksekutif dan Ukuran Perusahaan Pada Penghindaran Pajak. E-Jurnal Akuntansi Universitas Udayana. Vol.16.1. Juli (2016): 72-100.

Budiman, J., \& Sutiyono. (2012). Pengaruh Karakteristik Eksekutif Terhadap Peninghindaran Pajak (Tax Avoidance). Proceeding Simposium Nasional Akuntansi XV, Banjarmasin 25-28 September 2012.

Bisnis.liputan6.com 2000 perusahaan asing gelapkan pajak selama 10 tahun (http:// bisnis.liputan6.com/read/2469089/2000-perusahaan-asinggelapkan-pajak-selama-10-tahun), Diunduh 21 Desember 2016.

Chen, S, Chen, X., Cheng, Q., \& Shevlin, T. (2010). Are Family Firms More Tax Aggressive Than Non-family Firms?. Journal of Financial Economics, 95:41-61.

Coles, Jeffrey L.; Daniel, Naveen D.; dan Naveen, Lalitha. (2004). Managerial Incentives And Risk-Taking. The Accounting Review, J-33.

Davis, Angela K., Guenther, David A., Krull, Linda K., dan Williams, Brian M. (2013). Taxes and Corporate Accountability Reporting: Is Paying Taxes Viewed As Socially Responsible: Working Paper, Lundquist College of Buisness, University of Oregon.

Dharmasaputra, M. (2013). Saksi Kunci Investigasi Skandal Pajak Terbesar di Indonesia.

Tempo.(https://indonesiana.tempo.co/read/80481/2016/07/04/ahma d.yusdi28/login), Diunduh 6 Januari 2017.

Dewi, Ni Nyoman Kristiana dan Jati, I Ketut. 2014. Pengaruh KarakterkEksekutif, Karakteristik Perusahaan, dan Dimensi Tata Kelola Perusahaan yang 
Baik Pada Tax Avoidance di Bursa Efek Indonesia. E-Jurnal Akuntansi Universitas Udayana. Vol. 6, No. 2, Hal. 249-260.

Dyreng, S., Hanlon, M., dan Maydew, E. L. (2008). Long-Run Corporate Tax Avoidance. The Accounting Review Vol.83, 61-82.

Dyreng, S. D., Hanlon, M., dan Maydew, E. L. (2010). The Effects Of Executives On Corporate Tax Avoidance. The Accounting Review, 85(4), 1163-1189.

Delgado, F.J., E. F. Rodriguez, dan A. M. Arias. (2014). Effective Tax Rates in Corporate Taxation: a Quantile Regression for the EU. Inzinerine Ekonomika Engineering Economics, 25: 487-496.

Darmadi, Iqbal Nul Hakim dan Zulaikha. (2013). Analisis Faktor yang Mempengaruhi Manajemen Pajak dengan Indikator Tarif Pajak Efektif. Semarang: UNDIP, Diponegoro Journal Of Accounting Volume 2, Nomor 4, Tahun 2013, Halaman 1-12.

Dowling, John and Pfeffer, Jeffrey. (1975). Organizational Legitimacy: Social Values and Organizational Behavior. The Pacific Sociological Review.

Eisenhardt, KM. 1989. Agency Theory: An Assessment and Review. The Academy of Management Review, 14 (1), pp: 57-74.

Economy.okezone.com, Reformasi pajak, tax ratio Indonesia diharap tembus $20 \%$. (http:/ / economy.okezone.com/read/2016/09/02/20/1480013/reforma si-pajak-tax-ratio-indonesia-diharap-tembus-20), diunduh tanggal 20 januari 2017

Forumpajak.org. IKEA terjerat kasus penghindaran pajak http:// forumpajak.org/ikea-terjerat-kasus-penghindaran-pajak, Diunduh tanggal 23 Desember 2016.

Ghozali, Imam. 2016. Aplikasi Analisis Multivariate dengan Program IBM SPSS 23. Semarang. Badan Penerbit Universitas Diponegoro.

Gray, R., Kouhy, R. and Lavers, S. 1995. Corporate social and environmental reporting: a review of the literature and a longitudinal study of UK disclosure. Accounting, Auditing \& Accountability Journal, Vol. 8 No. 2, pp. 47-77.

Hanum, Hashemi Rodhian. (2013). Pengaruh Karakteristik Perusahaan Corporate Governance Terhadap Effective Tax Rate (ETR). Semarang: Undip, Diponegoro Journal Of Accounting.Volume 4, Nomor 4, Tahun 2015, Halaman 1-14.

Hanlon, M. and S. Heitzmann. (2010). A Review of Tax Research. Journal of Accounting and Economics, 50:127-178.

Hanafi, Umi dan Harto, Puji. 2014. Analisis Pengaruh Kompensasi Eksekutif, Kepemilikan Saham Eksekutif dan Preferensi Risiko Eksekutif Terhadap Penghindaran Pajak Perusahaan. Diponegoro Journal of Accounting.Vol.3, No. 2, Hal. 1-11.

Hackston, David and Milne, Marcus J. (1996). Some Determinants Of Social And Environmental Disclosures In New Zaeland Companies. Accounting, Auditing and Accountability Journal, Vol. 9, No. 1, pp. 77-108.

Hidayati, Naila Nuur dan Murni, Sri. (2009). Pengaruh Pengungkapan Corporate Social Responsibility Terhadap Earnings Response Coefficient Pada Perusahaan High Profile. Universitas Sebelas Maret Surakarta. Jurnal Bisnis Dan Akuntansi, Vol. 11, No. 1, April 2009, Hlm 1-18. 
Harsanti, Ponny. 2011. Corporate Social Responbility dan Teori Legitimasi. Majalah Ilmiah, Badan Penerbit Universitas Muria Kudus. Vol. 24, No.1, Juni 2011.

Jensen, Michael C., Mekling, William H. (1976). Theory of the firm: Managerial Behaviour, Agency Cost and Ownership Structure. Journal of Financial Economics, Vol 3, No.4.

Keputusan Ketua BAPEPAM No. Kep-29/PM/2004 Peraturan Nomor IX.15 tentang Pembentukan dan Pedoman Pelaksanaan Kerja Komite Audit.

Lanis, Robert and Grant Richardson. (2007). Determinants of Variability in Corporate Effective Tax Rate and Tax Reform : Evidence from Australia. Journal of Accounting and Public Policy 26, 689-704.

Lanis, Robert and Grant, Richardson. (2011). The Effect of Board of Director Composition on Corporate Tax Aggressiveness. J. Account. Public Policy, $50-70$.

Lanis, Robert and Grant Richardson. (2012). Corporate Social Responsibility and tax Aggressiveness: a test of legitimacy theory. J. Account. Public Policy 31, 86-108.

Luayyi, S., (2010). Teori Keagenan dan Manajemen Laba dari Sudut Pandang Etika Manajer. ELMUHASABA Vol 1 No.2.

Liu, X and S. Cao. (2007). Determinants of Corporate Effective Tax Rates. The Chinese Economy, Vol. 40 No. 6.

Low, A. 2006. Managerial Risk-Taking Behavior And Equity-Based Compensation. Journal Of Financial Economics, 92(3), 470-490.

Maccrimmon, K. R., \& Wehrung, D. A. 1990. Characteristics Of Risk Taking Executives. Management Science, 36(4), 422-435.

Maharani, I Gusti Ayu Cahya dan Suardana, I Ketut Alit. (2014). Pengaruh Corporate Governance, Profitabilitas dan Karakteristik Eksekutif pada Tax Avoidance Perusahaan Manufaktur. E-jurnal Akuntansi Universitas Udayana. Vol. 9, No. 2. Hal. 525-539.

Martini, Dwi dan Rusydi, M Khoiru. (2014). Pengaruh Struktur Kepemilikan tehadap Aggressive Tax Avoidance. SNA 17. 24-27 September 2014. Mataram, Lombok. Hal. 1-19.

Mardiasmo. 2008. Perpajakan. Edisi Revisi (2008). Yogyakarta: C.V. Andi Offset.

Mardiyanto, Handono, (2009). Intisari Manajemen Keuangan. Jakarta: Grasindo.

Mayangsari, Cindy. 2015. Pengaruh Kompensasi Eksekutif, Kepemilikan Saham Eksekutif, Preferensi Risiko Eksekutif dan Leverage terhadap Penghindaran Pajak (Tax Avoidance). Faculty of economics Riau University. Jom FEKON Vol.2 No.2 Oktober 2015.

Muzakki, M. R. (2015). Pengaruh Corporate Social Responsibility Dan Capital Intensity Terhadap Penghindaran Pajak. Skripsi. Fakultas Ekonomika dan Bisnis Universitas Diponegoro. Semarang.

Mulyani, Sri, Darminto dan Endang N.P, M.G WI. (2014). Pengaruh Karakteristik Perusahaan, Koneksi Politik dan Reformasi Perpajakan Terhadap Penghindaran Pajak (Studi Pada Perusahaan Manufaktur yang Terdaftar di Bursa Efek Tahun 2008-2012). Jurnal Mahasiswa Perpajakan Universitas Brawijaya. Vol. 2, No. 1. 
Nugraha, Novia Bani dan Meiranto, Wahyu. (2015). Pengaruh Corporate Social Responsibility, Ukuran Perusahaan, Profitabilitas, Leverage Dan Capital Intensity Terhadap Agresivitas Pajak. Semarang: Undip, Diponegoro Journal Of Accounting, Volume 4, Nomor 4, Tahun 2015, Halaman 1-14.

Noor, Rohaya Md., Nur Syazwani M. Fadzillah dan Nor Azam Matsuki. (2010). Corporate Tax Planning: A Study on Corporate Effective Tax Rates of Malaysian Listed Companies. International Journal of Trade, Economics and Finance, 1 (2): pp: 189-193.

Old.Wbcd.org. Corporate Social Responsibility. (http://old.wbcsd.org/workprogram/business-role/previous-work/corporate-socialresponsibility.aspx), Diunduh tanggal 15 januari 2017.

Paligorova, Teodora. (2010). Corporate Risk Taking and Ownership Structure. Bank of Canada Working Paper-3.

Peraturan BAPEPAM No. VIII.G.2 tentang Laporan Tahunan (annual report) Perusahaan.

Peraturan Pemerintah No. 46 Tahun 2013. Penyederhanaan perhituungan pajak wajib pajak badan.

Putri, Citra Lestari dan Lautania, Maya Febrianty. (2016). Pengaruh Capital Intensity Ratio, Inventory Intensity Ratio, Ownership Strucutre Dan Profitability Terhadap Effective Tax Rate (ETR). Universitas Syiah Kuala, Jurnal Ilmiah Mahasiswa Ekonomi Akuntansi (JIMEKA), Vol. 1, No. 1, (2016) Halaman 101-119.

Putra, I Gst Ln Ngr Dwi Cahyadi dan Merkusiwati, Ni Ketut Lely Aryani. (2016). Pengaruh Komisaris Independen, Leverage, Size dan Capital Intensity Ratio Pada Tax Avoidance. E-Jurnal Akuntansi Universitas Udayana, Vol.17.1. Oktober (2016): 690-714.

Rahmawati, Ayu, Endang, M.G. Wi dan Agusti, Rosalita Rachma. Pengaruh Pengungkapan Corporate Social Responsibility dan Corporate Governance Terhadap Tax Avoidance. Ilmu Administrasi Universitas Brawijaya. Jurnal Perpajakan (JEJAK), Vol. 10 No. 12016.

Rodriguez, E., F. And Arias, A., M. 2013. “Do Business Characteristics Determine an Effective Tax Rate?". The Chinese Economy, Vol. 45 No. 6.

Sembiring, E. R. (2005). Karakteristik Perusahaan dan Pengungkapan Tanggung Jawab Sosial: Studi Empiris pada Perusahaan yang Tercatat di Bursa Efek Jakarta. Simposium Nasional Akuntansi VIII .

Sudana, I. M., dan P.A. Arlindania. 2011. Corporate Governance dan Pengungkapan Corporate Social Responsibility pada Perusahaan GoPublic di Bursa Efek Indonesia. Jurnal Manajemen Teori dan Terapan.

Sugiyono. (2014). Metode Penelitian Bisnis. Bandung. Alfabeta.

Suyana Utama, Made. 2014. Aplikasi Analisis Kuantitatif. Edisi Kedelapan. Denpasar. Fakultas Ekonomi Universitas Udayana.

Susiloadi, P. (2008). Implementasi Corporate Social Responsibility untuk Mendukung Pembangunan Berkelanjutan. Spirit Publik, IV, 123-130.

Tempo.com Petinggi grup bakrie jadi tersangka kasus pajak (https://m.tempo.co/read/news/2010/03/22/090234327/lagipetinggi-grup-bakrie-jadi-tersangka-kasus-pajak) Diunduh tanggal 28 Desember 2016. 
Tilling, M.V. 2004. Refinement of Legitimacy Theory in Social and Enviromental Accounting. www.google.co.id. Diakses tanggal 2 Januari 2017.

Undang-Undang No. 28 Tahun 2007 tentang Ketentuan Umum dan Tata Cara Perpajakan.

Undang-Undang No. 40 tahun 2007 tentang Perseroan Terbatas.

Undang-Undang No. 25 tahun 2007 tentang Penanaman Modal.

Undang-Undang Dasar 1945 Amandemen III Pasal 23A.

Undang-Undang No. 36 Tahun 2008. Tarif pajak bagi wajib pajak badan.

Wahyudi, Dudi. 2015. Analisis Empiris Pengaruh Aktifitas Corporate Social Responsibility (CSR) terhadap Penghindaran Pajak di Indonesia. Proceeding Pertemuan Ilmiah Tahunan (PIT) Nasional ke-2 Ikatan Widyaiswara Indonesia (IWI) Provinsi Banten Pandeglang, 3 - 4 Desember 2015.

Xynas, L. (2011). Tax Planning, Avoidance and Evasion in Australia 1970-2010: The Regulatory Responses and Taxpayer Compliance. Revenue Law Journal Vol.20 Issue.1.

Yoehana, Maretta. (2013). Analisis Pengaruh Corporate Social Responsibility Terhadap Agresivitas Pajak. Semarang: Undip, Diponegoro Journal Of Accounting Volume 02 Nomor 02 Tahun 2013, Halaman 1-12. 